\title{
Is The Earth Dreaming Through Us?
}

\author{
Margaret Bowater
}

Transactional Analyst, Registered Psychotherapist, Auckland

\begin{abstract}
Recent research in dream science has established that we dream about the issues that matter to us emotionally: from immediate personal problems to spiritual and political issues. Indigenous cultures constantly call us to honour our relationship with Nature, and prophets throughout history have urged us to care for God's creation. Evolutionary psychology also suggests that a primary purpose of disturbing dreams is to raise issues that threaten our survival or wellbeing, so that we seek solutions. A major issue pressing on our consciousness now is the health of our very planet, the literal ground on which all life depends, so it is not surprising that some of us are having dreams and nightmares warning us that our environment is in great danger - as if the Earth itself is calling us to action. In this paper I consider a series of striking dreams from New Zealanders which are relevant to this theme.
\end{abstract}

\section{Waitara}

Kei ngā rangahau pūtaiao moemoeā o ko tata tonu atu nei e kī ana moemoeā ai tātou mō ngā take kare-ā-roto e ngākau nuihia ana e tātou: mai i ngā raruraru whaiaro tata, ki ngā take wairua atu ki ngā take tōrangapū. Kūmea tonuhia ai tātou ki te whakamānawa i tō tātou piri ki te ao tūroa, ā mai noa ngā tohunga e aki ana i a tātou ki te manaaki uri o ngā atua. E kì anō ana te mātai hinengaro kunenga ko te pūtake o ngā moemoeã whawhe he whakaara kaupapa whakawetiweti ake i te ora i te hauora rānei, ana ka rapu oranga haere. Ko tētahi kaupapa matua è pēhi ana i ō tātou hinengaro i tēnei wā ko te oranga o te ao, te mata o Papatūānuku, nōreira kāre noa iho e ohorere ana e moemoeā e kuku ana ētahi o tātou mō ngā whakatūpatotanga ki te āhua o te taiao - pēnei i te mea nei e whakaohohia ake ana tātou ki te whakatika. I roto i tēnei pepa ka whakaaro ake au i ngā moemoeā whai kiko mai i ngā tāngata o Aotearoa e pā ana ki tēnei kauapapa.

Keywords: dreams; dream reports; nightmares; environment; Nature; earthquakes; disasters

In choosing this topic for my paper I am combining three approaches. Firstly, I am acknowledging dreams as figures that arise out of the ground of sleep, when our brains 
switch off from our busy daytime concerns to give more attention to the psycho-spiritual issues in our inner world. This is classical ground for psychotherapy, religion and mythology. Secondly, the Conference theme of figure and ground encourages us to focus on major concerns which face our profession and our nation at this time. Thirdly, as we held our bicultural Conference in the magnificent location on Orakei Marae, overlooking the harbour and hills of Auckland, we may think of and about the actual ground on which we are privileged to stand.

\section{Sleep as Ground, Dreams as Figure}

Recent research, especially by Bulkeley (2007) and Domhoff (2007), has confirmed that our dreaming reflects issues of current emotional concern to the dreamer, bringing to the surface of consciousness thoughts, feelings and memories which have not been fully processed. Our human mammal brains require about one third of our life's time regularly for rest, refreshment, and the mysterious inner theatre of dreaming, where we find ourselves involved in observing, acting or interacting with a range of figures, animate and inanimate, which have something to show us or tell us - if we simply pay attention. This is not only about our human relationships, but also about our environment, as we can see from the selection of "earth-dreams" I present in this paper, dreams which warn us to wake up to growing dangers.

Sleep itself is a kind of ground, out of whichall our mental activities arise. Neuroscientist Allan Hobson gives a fascinating account of this in his beautiful book, Sleep (Hobson, 1989), demonstrating that the brain continues with purposeful activity while our bodies rest, seeming to be unconscious. In fact, approximately every 90 minutes, a cycle of brain waves creates a periodic burst of Rapid-Eye-Movement (REM) sleep, or active dreaming, when we are actually conscious, but in an alternate state, thereby paying attention to figures on the inner stage. Although Hobson is noted for his rather sceptical attitude to meaning in dreams, other dream scientists, (especially Barrett, 2001; and Hoss, 2005) have pointed out that REM sleep enables the brain to use a uniquely creative process for approaching our problems. While sleep may provide the under-ground of consciousness, dreams can be seen as figures that stand out to express our real concerns.

Linking this understanding with our current topic, let us consider our place on Earth as New Zealanders. We inhabit a group of islands on the Western Pacific rim, where two of the Earth's tectonic plates collide. We are therefore subject to volcanic eruptions and the continual jolts and shudders of earthquakes - over 20,000 per year, according to our GeoNet sensors (Morton, 2014) - of which we feel only about one a day. About one earthquake per decade, however, is really severe. Recently we were shocked into more awareness by the big ones that devastated Christchurch. So here is a dream that warns us to be more careful in future.

Margaret M, 78, an Aucklander, was visiting family in Wellington. A year and a half before, Christchurch had been hit by two major earthquakes, yet its risk level had been assessed much lower than that of Wellington. This is a shortened version of her dream: 


\section{Dream report \#1: Earth monster}

I dream I'm in a town focused on a volcano - the main street has this volcano at the end. One day when I am walking down the street, facing the volcano, I suddenly see that great clouds of steam and smoke are gushing out of it, and realise that it's erupting! Other people are seeing it and after a moment we all start running away from it, even though we have to run down a slope before running up. I wish there were more vehicles because I don't think we can outrun any lava flow straight ahead.

I calculate it may be safer to take a road off to the left which goes up another slope - at least it's out of the direct flow, though I can't be sure. I run up it and arrive at a large farm. The family is going about its ordinary afternoon. I ask if I may come in and tell them there's been an eruption, taking place as we speak. They listen but are not overly concerned. One woman however says she'll go and have a look and I go with her down a path. We hear tremendous cracking and falling noises and see huge trees falling downhill towards the sea between us and the volcano which is out of sight behind plantations. I observe from this view that of course the whole area is a giant caldera with great vertical rocky cliffs and a ring-like shape.

And then suddenly we see unmistakenly a monstrous creature made of rock dragging itself along the harbour floor towards the town and us. My companions gasp. The monster turns its head towards us far in the distance. I want to get up and run away somewhere. But I usually want to stay with other human beings even though they are slow to recognize danger.

Margaret found this dream very powerful, and related it directly to the earthquake risk in Wellington. She had just read a book about the high risk of a major earthquake in Wellington, which sits on a big faultline; it had had a huge earthquake 150 years ago, estimated at magnitude $8+$. She had been looking at the tall buildings in the city, and houses clinging to cliffs, thinking "How could people be so stupid?" She had lived previously in Christchurch, and was very upset about the devastation there. All New Zealanders are alert to the insecurity of our "shaky isles", and Aucklanders are reminded that our city is built on a volcanic field, which amongst other eruptions produced Rangitoto only 800 years ago, which could erupt again at any time.

Horrified at the rocky Monster rising from the crater floor, Margaret described it as "a huge, ancient creature of the Earth or Gaia or something." When she gave it a voice to express itself, the Monster poured out its frustration, saying it was fed up with being ignored: "Why don't you humans take notice of me? I'm very angry. I want to be acknowledged!" It was like a mythical god of the Earth, shaking itself out of slumber, ready to go on a rampage. Margaret was shaken by the dream, but felt helpless to take any action other than spread her concern.

However, as psychotherapists, we can take heed of the voice of the Earth warning us to be better prepared for crises to come. 


\section{The Environmental Crisis}

While economic issues and crime tend to dominate the headlines in our news, the most pressing issue is surely the crisis in our planet's environment, whereby pollution, overpopulation, and climate change threaten our very survival. We must lift our eyes beyond our traditional focus on individual wellbeing to include our responsibility for the wellbeing of our country and our planet.

The great tropical forests of Africa and South America, the lungs of the earth, are being destroyed for private profit. The world's atmosphere is becoming more polluted by release of too much carbon and methane, which causes the oceans to warm, which not only de-stabilises the planet's climate systems, generating violent storms, floods, droughts and forest fires, but also acidifies the oceans, destroys our fisheries, and threatens our beautiful coast-lines. Nearly all of our rivers and lakes are too polluted for safe swimming; our world-famous glaciers are shrinking; and much of what is left of our native bush is under threat from invading pests.

No wonder some of us are experiencing dreams and nightmares that call us to wake up! Not only our own country is calling us, but the whole Earth needs all of us to clean up our act. We are creatures of the Earth. Our bodies made from the nutrients held in the plants and animals that depend on the air and water and soil; and our minds are shaped in multiple ways by our environment. The whole system of life operates in a delicate balance, like a single macro-organism, and hence the Greeks intuitively named it Gaia, Goddess of the Earth. If that ecological balance is lost, we may never regain it. Most New Zealanders love to be in natural places like beaches, rivers, mountains, bush and open fields. It seems true at a symbolic level that as we attune ourselves to the struggle of Earth's living systems for survival, we will have dreams - nightmares - that express its desperation.

The most shocking dream I have heard on this theme of environmental danger was presented at one of my workshops, by Dudley, a man who had previously earned his living as a logger in tropical forests overseas. He now propagates native trees in New Zealand. Elsewhere, I wrote an article based on this dream (Bowater, 2009); this is a shortened version of Dudley's dream.

\section{Dream report \#2: Devastation of forests}

\section{Scene 1.}

I am with two old friends from my logging days, one Māori and one European. One is holding a chainsaw with an unrealistically long cutting bar. Then I am looking out over a landscape of stumps and debris where an exotic forest has been clear felled.

\section{Scene 2.}

As a side scene to this, in a kind of parallel dimension, not on the hillside, I'm in a small grove of native trees in dark or dim light, looking out to the clear-cut area in full sun. The trees I feel are special, like a ritual area, as they have missed not only the most recent felling but also an earlier land clearing. There is a sense of some spiritual presence but I cannot see anyone. 
Scene 3 .

I am coming over a hill in a clear-felled area to look down at the sea, which is about a kilometre away and presents as a broad panorama. The ground has been clear cut down to the water line. The sea itself is so full of logging debris, stumps, branches, etc., that I cannot see the water at all. As far as the eye can see the whole scene is a silver-grey colour and extremely graphic, surreal. The logging debris is gently undulating as waves move under it - an amazing scene of devastation, like the calm after a storm.

Scene 4 .

To my left, moving up the area between myself and the beach is an army of male loggers: zombie-like, hard hats on, no facial expression, moving forwards like an army on the march, with trucks and tractors among them, also in grey/silver and white, no colour. The dream ends.

As Dudley drew the series of scenes on the whiteboard it was clear that he was deeply moved by the dream. He explained that the stimulus had been watching a documentary produced by an eco-activist who had visited logging areas, sawmills, and such like, to raise public awareness about the effects of indiscriminate logging. This had obviously set in motion a parallel review of Dudley's own life, recalling the men who had been his colleagues in the forests where he had worked. Some of them were still friends, although Dudley had now moved into a different profession, and all of them had since become aware of the need for environmental protection.

What was new and shocking to him was the final scene of total devastation, and the blindness of the army of zombies who kept marching forward with no emotion about what they were doing. The scene was a massacre. Even the sea was choked with death. This wider, surrealistic quality is what marks the dream as a classical prophetic vision. A Biblical prophet might have said something like: "I saw in a vision the hills laid bare and the grey seas full of bones, and an army of blind men walking along the shore. Turn back, oh man, before too late!”

Responding to the group's questions, Dudley gave associations from his personal history. Then, using psychodrama, he gave a voice to the grove of native trees. It described itself as a sacred place, preserving the spirit of the forest, like a genetic pool: "This can never be lost," said the grove. "We hold the key, the template for nature. Even if it looks destroyed, it can't be totally lost." It was an archetypal symbol of hope in the midst of despair. Dudley had already heard its message in his life: he was actively involved in a business propagating native trees, and cleaning up the sea. Asked what he would do to create a new scene in the dream, he said he would stop the army and set them to replanting the land.

There are many elements of the dream worth noticing. The extra length of the cutting blade seems to emphasise its destructive power. The final scene is "silver-grey". The colour, or lack of it, belongs to twilight, day's end, approaching death; while the word "surreal" conveys the hyper-reality of many visionary experiences. In archetypal imagery, the sea often expresses emotion; here it heaves gently under its dreadful burden of dead 
trees, like the calm after a storm, as if it has given up protesting. The "army of male loggers" who show no emotion at all, are like soldiers who simply follow orders, doing what they are told; worse than slaves, here they are reduced to zombies, the walking dead: mindless creatures, unaware of their environment. Look, says the dream, "This is still happening now!”

The dream began like a personal review of Dudley's career in logging, but, with the inclusion of the polluted sea and the army of zombies, is suddenly expanded in its perspective with shocking clarity. The vision of the sacred grove adds a spiritual dimension, and demands a response from the whole world.

Whilst Dudley's dream reflected his life experience at a literal level, environmental disasters often feature in dreams metaphorically. Many people have dreams of tidal waves approaching them, symbolic of apprehension about circumstances about to overwhelm them. According to Ernest Hartmann (2007), this is actually the most common nightmare theme. Here is a recent example, in which the external landscape provides a metaphor for a woman's inner world.

Hannah, a journalist, was in a state close to exhaustion when she had a series of warning dreams. Their common theme was standing on land overlooking the sea, and observing that the waves were getting bigger. The third dream went further.

\section{Dream report \#3: Sea flooding in}

I'm on a hillside looking over the Bay. Huge waves are towering and rolling over the land, flooding all the low-lying residential area, where my mother lives, but I know she's somewhere else. I feel very worried, afraid. It all feels like overwhelm.

Hannah had a promised overseas commitment looming up, but was dreading the long trip. She was already overcommitted with work deadlines and study assignments. The dream message to Hannah was clear: her survival was at stake. It was time to cut her losses and retreat to safer ground; her inner Mother-self had already gone; she needed to cancel the trip and look after her health.

The impersonal forces of Nature, driven by atmospheric disruption, threaten "the way things are”, forcing us to adapt in order to survive. Although Hannah's dream had primarily a symbolic meaning, it also points to a reality for New Zealanders. As an island nation, our coastal settlements are at risk from the increased warming of the oceans and storms caused by atmospheric warming. We need to move back to safer ground. Some of our neighbours on Pacific atolls are already buying land in bigger countries in expectation that they will have to relocate.

Not only does Nature threaten us, so do the pressures of overpopulation and urbanisation, when city-dwellers colonise more of our wild places and fertile countryside, as the next two dreamers feared.

Arlene, a woman in midlife, went for a walk along the peaceful west-coast Te Henga | Bethells Beach north of Auckland, and sat on a rock to meditate. When she had finished she started walking back along the beach, and found herself in a different state of consciousness 


\section{Report of experience \#1: Beach vision}

I had a vision of myself waking up as if from a Rip Van Winkle type of sleep, and was now a hundred years away into the future. I could see a motorway along the length of the beach, connecting Bethells to other beaches, houses and apartments on the grass area, and a lot of people walking about but not swimming or going into the water. I felt despair at this sight on the once level and quiet beach. The vision lasted a couple of minutes, and during it I realized that my car would not be where I had left it; I was dressed differently from the people I could see, and life as I had known it had changed dramatically.

Following this report, she reflected:

"I hoped it was not a prophecy of things to come.I have been meditating for several years, but only recently started doing this in nature, after receiving a message and image during a meditation to do this. My meditation is usually contemplative/ reflective, where the focus is on a meaningful phrase or word. On this particular day I was intent on listening to the sound of the ocean and waves on the beach, and breath awareness."

This vision created despair in Arlene, warning of a future in which places of natural peace and beauty will be destroyed by heedless urbanization unless we take action to preserve them. The issue is very alive today, as local groups in this country rally to prevent the expansion of vast dairy-farms on marginal land, marinas in estuaries, open-cast coalmining, and deep-sea oil-drilling.

On a similar theme, a man who had left city life to make his home in the country had become increasingly alarmed at the expansion of cities into rural zones, and highways bringing holiday-makers further into the countryside, turning peaceful little villages into busy play-grounds for the rich. His dream expresses both anger and humour. Maurice was a man in midlife, living in the countryside, with a love of nature and a detestation of the encroachment of city roads and wealthy housing into the natural environment. He presented this dream at a workshop.

\section{Dream report \#4: Roadworks blow-up}

I am going down a steep hill in some vehicle in which there appears to be little between me and the gravelly road ahead - a bit like being in one of those carts kids make. Not a great deal of control either. There are a number of earth-moving machines working to my left and below me, and some quite large over-ostentatious houses on my right.

Suddenly there is an explosion at the bottom of the hill, a large puff of smoke. I try to turn, and have to enter one of the driveways to the houses in order to do this. I sense a reticence about entering this driveway - like they are rich people and not very nice - and then I am racing up the hill to escape. The road-machines have also fled and begin to race up the side of the road, some exploding as if hit by a weapon of some kind. They really are fleeing. They have become animated 
caricatures of earth movers, leaping and ducking all over the place, racing here and there in a demented cartoon fashion.

Then I am in a graveyard of old earthmoving and industrial machinery. I am sitting on a seat-type thing, like an interactive museum, and a young man comes along. He plays with some levers and my chair begins to rise. I feel vulnerable. The machine topples, and I think how silly he is to play with such dangerous things, and how I could quite easily be injured. I am not injured at all, and just tell the young man to be careful. I am thinking that I don't want him to feel bad about what has just happened.

As Maurice began to express his associations with the elements of the dream it became clear that he held strong feelings about the loss of natural environments to wealthy suburbs and resorts. The big machines are thus symbols of the "fat cat" invaders and destroyers. When the explosion occurs, he is delighted to see them fleeing in fear, tumbling over each other, so disorganized that they are laughable. Scene 2 seems to take a jump into the future, when the machines have "died," and become museum pieces. Young people coming to look at the past even try to play with them, not realizing how dangerous these things were and still are, causing us to lose our balance.

The theme of man-made destruction of Nature takes a sinister twist in scientists' more recent recognition that certain agricultural chemicals could actually destroy the whole food-chain, by killing the simple honeybees that fertilise our plants. Here is a dreamsequence illustrating this.

As a child, Janine had developed a love of nature, and learned to play the violin. At 60 , she became worried about the diminishing bee population, and came up with the idea of playing music in nature as a meditative exercise:

"So I took my violin and video camera and I played music in sacred spaces that I often go to in the Waitakere bush. I thought I could strengthen the bees with healing vibrations. I did this gesture of music playing a few times and then I had this dream."

\section{Dream report \#5: Happy bee colony}

I dreamt that I was in a very happy environment. It was a sunny place with lots of people, and my yoga teacher was like a facilitator. There was so much joy and laughter that I was aware of. Then out of nowhere bees came from everywhere, not in a scary but in a wondrous way.

"When I woke I thought: 'Wow, that was a lovely dream, filled with hope.' Not long after this dream, we needed some work done on our property and we called in a drain layer. He was a local man and an ardent bee keeper. We talked a lot about bees. He offered to bring one of his hives and place it on our property. It was magic. We became very involved and learnt the art of bee keeping. We went to bee school to inform us of how to improve our knowledge and care of the bees. We had a very strong hive and we extracted a lot of honey, which we gave to lots of people. We weathered the wet winter and the bees seemed to do well. They were a strong 
hive. Then on 4th October 2012 I woke up after a very disturbing dream.”

\section{Dream report \#6: Tidal wave destruction}

I am home in my family-of-origin house in Seatoun Heights, Wellington. There is an enormous tidal wave: muddy water; fierce, big powerful waves; the surge of water was violent and destructive. However, the house was sturdy and withstood the pounding water. The houses in the valley had all been submerged. There were images of chooks being thrown against the wire netting. Then another wave struck slightly less and lasting a shorter time. An old friend appears, and we travel in a car to view the damage, and another wave strikes. Much less this time and we are safe. Then we notice the water has receded from the valley and people have survived. Their houses have been demolished but they are getting themselves back together. The people in the dream are people from my past and from a community that I once had a strong connection to: people who were preparing for future upheaval; resilient and strong people.

"It was one of those dreams you wake up from and it feels like you are still in it: very vivid images and a sense that something is not right.

Then we found signs of dead bees on the doorstep. Next day a visit inside the hive revealed the dreaded news of American foul brood disease. A second opinion confirmed it. There is only one action to take; there is no mucking around. Killing the bees that day was indeed one of the saddest events of our lives in terms of having to kill the creatures we had developed such a strong appreciation and love of. We know that this dreaded disease has to be dealt with.

Was the dream a premonition? I know we did the right thing for the bee realm."

Janine's story shows how fully she was "tuned in" to nature, and supporting the vital role of the happy little bees on whom the flourishing of nature so depends, which of course affects our own human survival. The destruction of the hive is foretold in the prophetic dream of the tidal waves destroying human habitation; parallel to the awful decision that the bees' owners had to take, to destroy the whole hive. Yet the dream also carries hope. The people are resilient, and will recover from this disaster. There are steps to be taken, lessons to be learned from the enormous loss - and, in fact, the world-wide honey industry has been moving fast to protect the bees.

\section{Our Turangawaewae}

As we held our bicultural conference in this magnificent location at Orakei Marae overlooking the harbour and hills of Auckland, we thought of the actual ground on which we are privileged to stand: the ancestral home of the Ngati Whatua people, who originally gifted land to our European ancestors to settle nearby. It is also a place of historic confrontation between Māori and Pākehā, when in 1978, to our shame, the New Zealand government sent a huge contingent of police to evict about 200 Māori from this last block of their own land. Under the Waitangi Tribunal, it was restored 13 years later, and a 
new Marae was built, onto which our Conference was welcomed in a spirit of reconciliation. This meeting ground is a sacred space.

While Pākehā settlers have not been in New Zealand nearly as long as Mãori, many of us are descended from farming families who have also loved this land, its hills and mountains, rivers and lakes, bush and coasts, and who also want to preserve its beauty for future generations. I know that I frequently dream of landscape scenes as metaphors for journeys and struggles, but I recall one dream in particular that startled me.

\section{Dream report \#7: Place of identity}

I was gazing at a lovely little blue-grey lake surrounded by raupo reeds, nestling at the foot of tall lupin-clad sand-hills on one side and green hills of farmland on the other. There were black swans on the lake. A voice said: "This is your place of identity."

The scene was familiar to me from my childhood years at Kohe Kohe on the Manukau Peninsula. We children roamed freely around the hillsides and often went on family picnics over the sand-hills to the black sand beach on the West coast. Our family lived in the old kauri building that had been the Kohe Kohe School for 60 years. Years later I learned the history of the lake. It had originally been a Mãori tribal fishing place for eels, and the shape of kumara pits can still be seen on the hills around it. Later it became the scene of a small flax-milling venture, before European settlers cleared the land for farming. So I claim the memory of this place as my own strongest point of attachment to our landscape.

\section{Conclusion - The Earth's nightmares}

For all our intellectual achievements, we are still creatures of the Earth, and we dream about our real concerns. Some people, like the Prophets of old, are having nightmares about the dangers of the new crisis that threatens the survival of humanity on Earth. Science has now shown us that all life on earth is interdependent in a complex macroecological system. As we human beings are carrying the consciousness of the Earth, it could be said that the Earth is dreaming through us, to awaken us to its increasingly desperate plight. We can all respond!

\section{References}

Barrett, D., \& McNamara, P. (Eds.). (2007). The new science of dreaming (3 Vols.). Westport, CT: Praeger.

Bowater, M. M. (2009). Forest devastation - a prophetic vision. Dreamtime, 26(3).

Bulkeley, K. (2007). Sacred sleep: Scientific contributions to the study of religiously significant dreaming. In D. Barrett \& P. McNamara, P. (Eds.). The new science of dreaming (Vol.3; pp. 71-94). Westport, CT: Praeger.

Domhoff, G. W. (2007). Realistic simulation and bizarreness in dream content: Past findings and suggestions for future research," In D. Barrett \& P. McNamara, P. (Eds.). The new science of dreaming (Vol 2; pp.1-27). Westport, CT: Praeger. 
Hartmann, E. (2007). The nature and functions of dreaming. In D. Barrett \& P. McNamara

(Eds.). The new science of dreaming (Vol 3; pp. 171-192). Westport, CT: Praeger.

Hobson, J. A. (1989). Sleep. New York, NY: Scientific American Library.

Morton, J. (2014, $3^{\text {rd }}$ February). Big quakes no reason to pack the bags. New Zealand Herald, p.

A2O.

\section{Acknowledgement}

All dreams are quoted with their authors' permission.

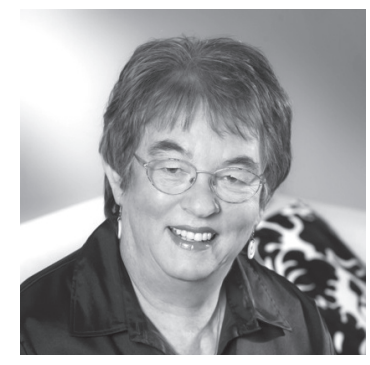

Margaret Bowater, MA, TSTA, Registered Psychotherapist, MNZAP, MNZAC is a Teaching and Supervising Transactional Analyst, and is well-known in New Zealand as a teacher, writer and facilitator of Dreamwork. She was a Founding Director of the Human Development and Training Institute in Auckland. She runs New Zealand's only Certificate in Applied Dreamwork, and is New Zealand's Liaison representative to the International Association for the Study of Dreams. She is the author of Dreams and Visions: Language of the Spirit (Tandem Press, 1997) and of numerous articles published in international journals. Contact details: mbowater@clear.net.nz . 